\title{
MODIFICATION OF A BRAZILIAN SMECTITE CLAY WITH DIFFERENT QUATERNARY AMMONIUM SALTS
}

\author{
Maria Flávia Delbem, Ticiane S. Valera, Francisco R. Valenzuela-Diaz e Nicole R. Demarquette* \\ Departamento de Engenharia Metalúrgica e de Materiais, Escola Politécnica, Universidade de São Paulo, Av. Prof. Mello Moraes, \\ 2463, 05508-900 São Paulo - SP, Brasil
}

Recebido em 20/2/09; aceito em 19/8/09; publicado na web em 11/1/10

\begin{abstract}
In this work, a smectite clay from the State of Paraiba, Brazil, was treated with six different types of ammonium salts, which is an usual method to enhance the affinity between the clay and polymer for the preparation of nanocomposites. The clays, before and after modification, were characterized by $\mathrm{X}$ ray diffraction. The conformation of the salts within the platelets of the clay depended on the number of long alkyl chains of the salt. The thermal stability of the clays was also studied. The ammonium salts thermal decomposition was explained in light of their position within the organoclays.
\end{abstract}

Keywords: alkyl quaternary ammonium salts; thermal stability; Brazilian smectite clay.

\section{INTRODUCTION}

For the last 20 years, a great number of studies has been conducted on the subject of clay containing polymer nanocomposites due to the interesting structure and improved properties these materials present. ${ }^{1-9}$ Polymer clay nanocomposites are normally obtained through the dispersion of clays chemically modified, within a polymer matrix either by in situ polymerization, melt intercalation or solution casting..$^{2,4,5}$ Melt intercalation is the most promising method in a large scale. ${ }^{2,4,5,7,8}$ It consists of mixing the clay with the polymer in the molten state using conventional polymer processing techniques. However, when using this preparation method care should be taken that the chemical treatment of the clay to enhance the interaction between the clay and polymer within the composite, be resistant to the high temperatures and oxidative atmosphere during processing., ${ }^{2,4}$

The clays most commonly used to obtain nanocomposites are the ones from the smectite group, particularly the montmorillonite. ${ }^{3,9,10}$ These smectitic clays exhibit a large variety of properties which turn them attractive to be used to obtain clay containing polymer nanocomposites: their particles have naturally small dimensions with average sizes smaller than $2 \mu \mathrm{m}$, they have a large specific area and their individual layers are reactive. Also, it is possible to exchange the metallic cations present between the layers by organic cations turning them organophilic. ${ }^{3,9-12}$ These organic cations have a physicochemical affinity with organic solvents (which can be used to polymerize the polymers) or polymer matrices (if the clay containing polymer nanocomposites are to be obtained by melt blending). Usually, in order to use the smectic clays in nanocomposites, the metallic cations are substituted by quaternary ammonium or other heteroatom organic salts. ${ }^{3,9,10}$ The method used to exchange the metallic cations by organics ones has a strong influence on the structure of the resultant organoclay. ${ }^{10,13}$ The use of different smectite clays, different organic cations, levels of adsorption and amounts of salts are the main parameters that control the obtention of organophilic clays with different properties ${ }^{14}$ During the preparation of clay containing polymer nanocomposites by melt intercalation (or melt blending) it is possible that the organic salts will not be stable, so that they may decompose, affecting the resulting clay interlayer spacing

*e-mail: nick@usp.br and its affinity to the polymer. Therefore, it is very important to study the oxidative thermo-degradation of the organoclays prior to nanocomposite preparation. Many studies have been conducted regarding the thermal stability of organic cations. ${ }^{15-24}$ The studies reported in the literature ${ }^{15-24}$ showed that the degradation of the salts is mainly thermally driven, with a slight increase of the surfactant mass loss in air atmosphere when compared to the one in nitrogen atmosphere. These studies ${ }^{15-24}$ also indicated that the initial degradation of salts follows a Hoffman elimination reaction, producing alpha olefins, amines and other products from secondary reactions between the degradation products.

Organoclays have the ability to swell and disperse in organic solvents, and have been widely used in a range of applications such as thickening and gelling of paints, lubricants and cosmetics, as a filter material for water purification and as sorbent in pollution prevention and environmental remediation. A detailed review about the application field of organoclays can be found in Bergaya, Theng and Lagaly. ${ }^{3}$ The great interest in organoclays and the large source of smectite clays in the Brazilian territory ${ }^{12}$ provides a great opportunity for developing organoclays in Brazil. However, in spite of the large number of works about polymer matrix/clay nanocomposites, only few works relate the use of organoclays of Brazilian origin..$^{2,25-34}$ Most works use clays from American, Japanese and Chinese origin. ${ }^{2,9,24}$ Therefore it is of great interest to study the organofilization of Brazilian clays and their resistance to temperature since to our knowledge, a systematic study on the thermal stability of Brazilian organoclays has never been reported in the literature.

In this paper, a Brazilian clay from the State of Paraíba, Northeastern Brazil, was used. It was modified using commercial quaternary ammonium salts instead of PA grade salts in order to keep the process cost low. Six different types of ammonium salts were used, namely: diestearildimethylammonium chloride - DEDMA, ditallowalkyldimethylammonium chloride - DTADMA, dialquildimethylammonium chloride - DADMA, alquildimethylbenzylammonium chloride - ADMBA, hexadecyltrimethylammonium chloride - HDTMA, fettalkyldimethylhydroxiethylammonium chloride - FADMHEA. The organoclays were characterized by X ray diffraction and foster swelling degree. The thermal stability of the organically modified clays was studied in view of using those clays for preparation of polyolefins nanocomposites by melt blending. 


\section{EXPERIMENTAL}

\section{Materials}

The clay used in this work was a polycationic smectite clay, predominantly montmorillonite, denominated verde-claro (VC), from Boa Vista city, the State of Paraíba, Northeastern Brazil (geographic coordinates of source of VC clay: latitude $-7.18^{\circ}$, longitude $-36.15^{\circ}$ ). Its cation exchange capacity (CEC) is 93 meq/100 g, obtained by Kjeldahl ammonia distillation method..$^{35,36}$ The clay was ground to 200 mesh sieve and used without further purification. Table 1 presents the chemical composition of VC smectite clay, determined by $\mathrm{X}$ ray fluorescence. More information about the clay can be found in Valenzuela'works. ${ }^{37-39}$ Quaternary ammonium salts of different structures were used to turn the clay organophilic. Their properties are shown Table 2. The more stable conformation for the organic cations were calculated using Hyper Chem $^{\mathrm{TM}} 6.01$ software and are shown Table 2.

\section{Organoclay preparation}

VC smectite clay is polycationic, hence the metallic ions occupying the interlayer space (predominantly $\mathrm{Ca}^{2+}$ ) had to be changed by sodium ions $\left(\mathrm{Na}^{+}\right)$: for that the clay was dispersed in deionized water ( 4 wt. $\%$ of clay) and $\mathrm{Na}_{2} \mathrm{CO}_{3}$, at a concentration of $100 \mathrm{meq} / 100 \mathrm{~g}$ of clay, was slowly added to the suspension. The suspension was stirred for about $30 \mathrm{~min}$ at $97^{\circ} \mathrm{C}$. Then, an aqueous solution of quaternary ammonium salt was added to the suspension containing sodium smectite clay (VC-Na), at a concentration equivalent to 1.1 CEC of the sodium clay. After stirring for $30 \mathrm{~min}$ at room temperature, the suspension was filtered and washed with deionized water until free of chlorine ions. The organophilic clays were then dried at $60{ }^{\circ} \mathrm{C}$ for $48 \mathrm{~h}$, ground and stored at room temperature. The experimental details of the clay preparation are described elsewhere..$^{37,40}$

\section{Swelling degree}

The swelling degree was applied as a method to obtain the degree of affinity of the organoclays for organic compounds. This analysis is based on Foster's work ${ }^{41}$ and the experimental procedure is as follows: $1 \mathrm{~g}$ of clay (VC-Na: $\mathrm{VC}$ before treatment with quaternary ammonium salts or $\mathrm{VC}-\mathrm{O}$ : $\mathrm{VC}$ modified with quaternary ammonium salts) is added to a graduated cylinder containing $50 \mathrm{~mL}$ of organic solvent. The sedimentation of the clay particles occurs after $1 \mathrm{~h}$. Then, the suspension is mixed and the volume of swelled clay is

Table 1. Chemical composition of VC smectite clay

\begin{tabular}{cc}
\hline Oxide & wt.\% \\
\hline $\mathrm{SiO}_{2}$ & 63.6 \\
$\mathrm{Al}_{2} \mathrm{O}_{3}$ & 18.2 \\
$\mathrm{Fe}_{2} \mathrm{O}_{3}$ & 12.6 \\
$\mathrm{MgO}$ & 2.28 \\
$\mathrm{CaO}$ & 0.67 \\
$\mathrm{Na}_{2} \mathrm{O}$ & 0.55 \\
$\mathrm{TiO}_{2}$ & 1.18 \\
$\mathrm{~K}_{2} \mathrm{O}$ & 0.46 \\
$\mathrm{P}_{2} \mathrm{O}_{5}$ & 0.06 \\
$\mathrm{SO}_{3}$ & 0.02 \\
$\mathrm{Cl}_{2}$ & 0.30 \\
$\mathrm{~V}_{2} \mathrm{O}_{5}$ & 0.01 \\
$\mathrm{Cr}_{2} \mathrm{O}_{3}$ & 0.05 \\
$\mathrm{MnO}$ & 0.01 \\
$\mathrm{NiO}_{\mathrm{CuO}}$ & 0.02 \\
$\mathrm{ZnO}_{\mathrm{Rb}} \mathrm{O}$ & 0.01 \\
$\mathrm{SrO}_{\mathrm{Y}_{2} \mathrm{O}_{3}}^{\mathrm{ZrO}}$ & 0.03 \\
& 0.01 \\
\hline & 0.01 \\
\hline
\end{tabular}

Table 2. Alkyl quaternary ammonium salts used in this work

\begin{tabular}{|c|c|c|c|}
\hline Salts & Formula & Designation & Structure \\
\hline $\begin{array}{l}\text { diestearildimethylammonium } \\
\text { chloride }\end{array}$ & {$\left[\left(\mathrm{CH}_{3}\right)_{2}\left(\mathrm{C}_{18} \mathrm{H}_{37}\right)_{2} \mathrm{~N}^{+}\right] \mathrm{Cl}^{-}$} & DEDMA (1) & \\
\hline $\begin{array}{l}\text { ditallowalkyldimethylammonium } \\
\text { chloride }\end{array}$ & $\begin{array}{c}{\left[\left(\mathrm{CH}_{3}\right)_{2} \mathrm{R}_{2} \mathrm{~N}^{+}\right] \mathrm{Cl}^{-}} \\
\mathrm{R}=\sim 65 \% \mathrm{C} 18 ; \sim 30 \% \mathrm{C} 16 \\
\sim 5 \% \mathrm{C} 14\end{array}$ & DTADMA (1) & \\
\hline dialkyldimethylammonium chloride & $\begin{aligned} & {\left[\left(\mathrm{CH}_{3}\right)_{2} \mathrm{R}_{2} \mathrm{~N}^{+}\right] \mathrm{Cl}^{-} } \\
\mathrm{R}= & \sim 70 \% \mathrm{C} 12 \mathrm{e} \sim 30 \% \mathrm{C} 14\end{aligned}$ & DADMA (2) & \\
\hline $\begin{array}{l}\text { alkyldimethylbenzylammonium } \\
\text { chloride }\end{array}$ & $\begin{array}{c}{\left[\left(\mathrm{CH}_{3}\right)_{2}\left(\mathrm{CH}_{2} \mathrm{C}_{6} \mathrm{H}_{5}\right) \mathrm{R} \mathrm{N}^{+}\right] \mathrm{Cl}^{-}} \\
\mathrm{R}=\sim 2 \% \mathrm{C} 10 ; \sim 50 \% \mathrm{C} 12 \\
\sim 24 \% \mathrm{C} 14 ; 13 \% \mathrm{C} 18 \mathrm{e} \sim 11 \% \mathrm{C} 16\end{array}$ & $\operatorname{ADMBA}(1)$ & \\
\hline $\begin{array}{l}\text { hexadecyltrimethylammonium } \\
\text { chloride }\end{array}$ & {$\left[\left(\mathrm{CH}_{3}\right)_{3}\left(\mathrm{C}_{16} \mathrm{H}_{33}\right) \mathrm{N}^{+}\right] \mathrm{Cl}^{-}$} & HDTMA (1) & \\
\hline $\begin{array}{l}\text { Fettalkyldimethylhydroxyethylam- } \\
\text { monium chloride }\end{array}$ & {$\left[\left(\mathrm{CH}_{3}\right)_{2}\left(\mathrm{C}_{18} \mathrm{H}_{37}\right)\left(\mathrm{C}_{2} \mathrm{H}_{4} \mathrm{OH}\right) \mathrm{N}^{+}\right] \mathrm{Cl}^{-}$} & FADMHEA (1) & $O c$ \\
\hline
\end{tabular}


measured after $24 \mathrm{~h}$. The values are reported in $\mathrm{mL} / \mathrm{g}$. According to Valenzuela-Diaz ${ }^{40}$ the swelling degree of clays can be classified as: Non swelling: values less than $2 \mathrm{~mL} / \mathrm{g}$; Low swelling: values between 3 and $5 \mathrm{~mL} / \mathrm{g}$; Medium swelling: values between 6 and $8 \mathrm{~mL} / \mathrm{g}$; High swelling: values $>8 \mathrm{~mL} / \mathrm{g}$.

\section{$\mathrm{X}$ ray diffraction $(\mathrm{XRD})$}

The clays (sodium and organo) were analyzed by X ray diffraction using a Philips X'Pert-MPD diffractometer. XRD patterns were recorded using $\mathrm{Cu} \mathrm{k} \alpha$ radiation $(\lambda=1.54056 \AA)$ and scanning rate of $1^{\circ}(2 \theta) / \mathrm{min}$. The analyses were performed using samples that were all kept in same weathering condition (constant relative humidity and temperature). The basal spacing $\left(\mathrm{d}_{(001)}\right)$ of clays was calculated using Bragg's law.

\section{Thermal analysis (TG-DTA)}

Thermogravimetric analysis (TG) and differential thermal analysis (DTA) of the clay before and after modification were obtained in simultaneous TG-DTA, from TA Instruments, model SDT 2060. $16 \mathrm{mg}$ of sample were placed in an alumina crucible and submitted to a range of temperatures from 25 to $1000^{\circ} \mathrm{C}$, at a heating rate of $10^{\circ} \mathrm{C} / \mathrm{min}$. Heating rates of 5 and $10^{\circ} \mathrm{C} / \mathrm{min}$ were used and the results obtained were similar. The purge gas was air at a flow rate of $50 \mathrm{~mL} /$ min to simulate standard polymer processing conditions.

\section{RESULTS AND DISCUSSION}

\section{X-ray diffraction}

Figure 1 shows the XRD patterns of the VC clay before and after modification using the different alkyl quaternary ammonium salts presented in Table 2 . The basal spacing $\left(\mathrm{d}_{(001)}\right)$ values of sodium and organophilic clays are presented in Table 3 . Table 3 also presents the layer opening of clays after organic cation intercalation, that is, the difference between basal spacing value of sodium and organophilic clays. The $\mathrm{d}_{(001)}$ of sodium clay was found to be $1.52 \mathrm{~nm}$, which is characteristic of an hydrated montmorillonite. A completely anhydrous VC-Na had a d ${ }_{(001)}$ of $0.96 \mathrm{~nm} .{ }^{42}$ The layer opening of $0.56 \mathrm{~nm}$ (1.52 minus 0.96) corresponds to the presence of two water layers in the interlayer space. ${ }^{42}$ The XRD patterns presented in Figure 1 show that after modification of the VC-Na clay with quaternary ammonium salts, the diffraction peaks shift to smaller angle values proving the intercalation of the organic cations between the silicate layers. It can be seen in Figure 1 and Table 3 that the organoclays prepared from two-tailed salts (VC-DEDMA, VC-DTADMA and VC-DADMA) present higher basal spacing values, ranging from 2.9 to 3.6, indicating that the alkylammonium ions are disposed in paraffin-type arrangements in the interlayer space of clay. ${ }^{3}$ The organoclays with one-tailed salt present basal spacing values of 1.90 (FADMHEA) and about $2.20 \mathrm{~nm}$ (HDTMA and ADMBA) indicating bilayer (flatlying alkylammonium ions) and pseudotrimolecular (surfactant group is attached on the silicate layers and the alkyl chain assume a trimolecular arrangement by formation of kinks) arrangements in the galleries, respectively. ${ }^{3}$ These possible conformations are shown Figure 2. Figure 1 also shows that the two-tailed salt organoclays exhibit higher order peaks corresponding to (002) and (003) planes of montmorillonite. These higher order peaks suggest that the two-tailed salt clays present a well ordered layer structure. The intensity of the diffraction peak corresponding to (001) plane of the VC-DEDMA and VC-DTADMA was increased when compared to one of sodium clay, possibly because of an increase layer order.

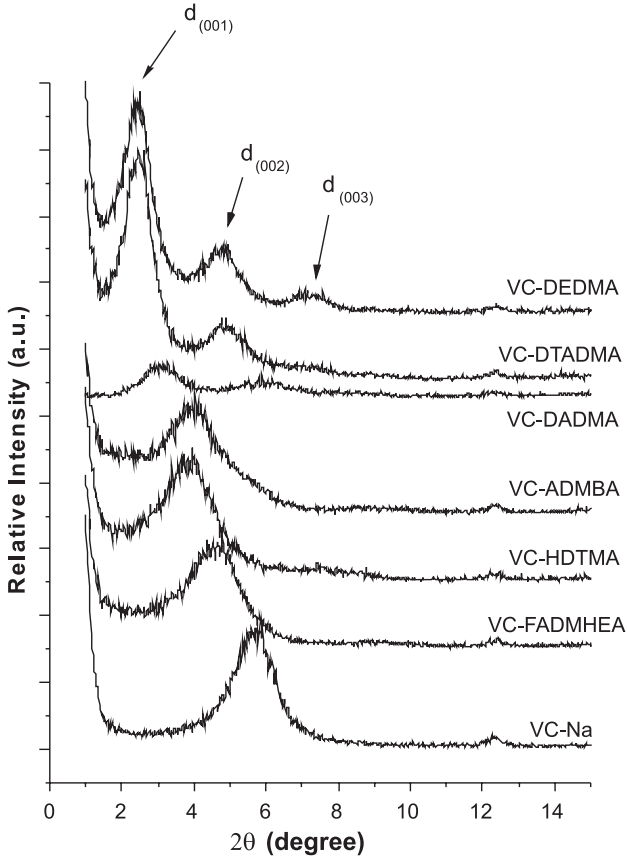

Figure 1. XRD patterns of VC-Na before and after modification with different alkyl quaternary ammonium salts (VC-DEDMA, VC-DTADMA, VC-DADMA, VC-ADMBA, VC-HDTMA and VC-FADMHEA)

Table 3. Basal spacing values of the sodium and modified VC clay

\begin{tabular}{lcc}
\hline Clay & $\mathrm{d}_{001}(\mathrm{~nm})$ & Layer opening $(\mathrm{nm})$ \\
\hline VC-Na & 1.52 & 0.56 \\
VC-DEDMA & 3.62 & 2.10 \\
VC-DTADMA & 3.58 & 2.06 \\
VC-DADMA & 2.86 & 1.34 \\
VC-ADMBA & 2.19 & 0.67 \\
VC-HDTMA & 2.29 & 0.77 \\
VC-FADMHEA & 1.90 & 0.38 \\
\hline
\end{tabular}

The hydrophobization of clays by adsorption of ammonium salts is an important step for application of the clays as fillers for polymer nanocomposites. The surface modification of Brazilian clays was qualitatively evaluated by its swelling degree in organic solvent (expansion of clay galleries to accommodate the intercalated solvent). Figure 3 presents the Foster swelling degree of organoclays in xylene. The degree of affinity of all organoclays for the organic compounds was increased as compared to the one of sodium clay. It can be seen from Figure 3 that the two-tailed organoclays present higher swelling degree than the one-tailed organoclays. This can be easily explained by the configuration of the salts within the clays platelets. The $\mathrm{X}$ ray diffraction results shown above indicated that the two-tailed salt clays show paraffin-type arrangements in the interlayer space and that the one-tailed salt clays exhibit pseudotrimolecular and bylayer arrangements. The pseudotrimolecular or bylayer is a denser structure than the paraffin-type arrangements which results in a smaller accessible volume within the galleries, that is, the empty spaces between the alkylammonium ions. The high swelling degree value of two-tailed salt clays in organic compounds indicate that they can adsorb significant amounts of organic fluids, comprising benzene, toluene, diesel, gasoline, kerosene and others. Therefore, besides the role of nanocomposite filler, they are potential candidates for environmental applications, such as in oil spill cleanup operations, and for the removal of aromatics.,43 


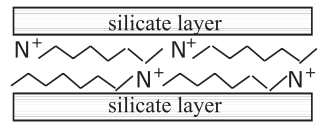

(a)

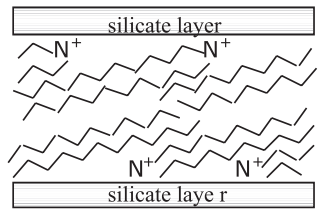

(c)

Figure 2. A schematic representation of the possible arrangements of the ammonium quaternary salts in the interlayer space of a smectite clay: (a) bilayer, (b) pseudo-trimolecular layers, and (c) paraffin-type arrangements (adapted from reference 3). (a) and (b) present one-tailed alkyl ammonium salts, and (c) presents two-tailed alkyl ammonium salts

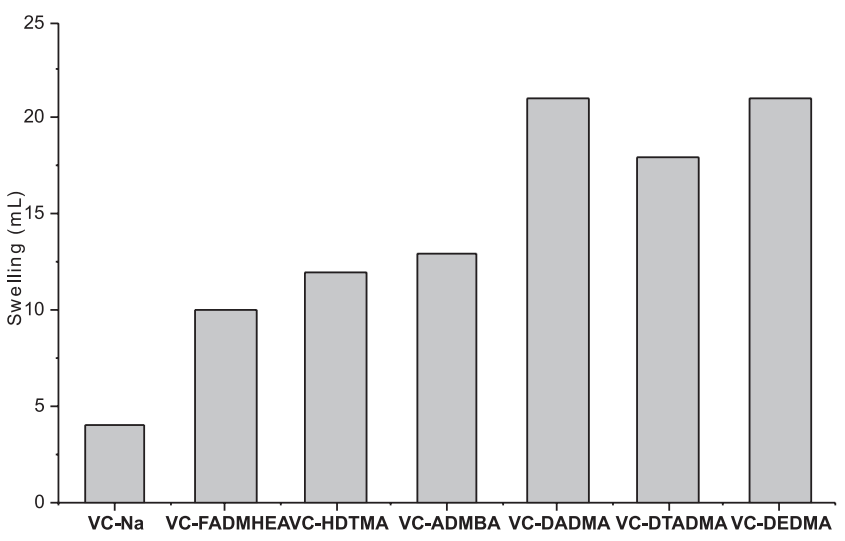

Figure 3. Swelling degree of organoclays

\section{Thermal analysis}

The thermal stability of the organic cations is a main issue when organoclays are used to prepare nanocomposites by melt intercalation. Figure 4 shows the results of the differential thermal analysis (DTA) of sodium and organophilic clays, and Figure 5 shows mass loss curves of the clays studied here.

The DTA curve of the sodium clay shows two endothermic peaks, labeled 1 and 2, and one small S-shaped endo-exothermic peak, labeled 3, which correspond to: ${ }^{15,16,24}$

Peak 1 - mass loss of gaseous species and mass loss associated with the dehydration of the clay (between 25 and $200{ }^{\circ} \mathrm{C}$ ); Peak $2-$ mass loss associated with the dehydroxylation of the smectite layers (between about 450 and $550{ }^{\circ} \mathrm{C}$ ); Peak 3 - formation of new phases such as spinel, and mullite (between 800 and $1000^{\circ} \mathrm{C}$ ).

The DTA curves of the modified clays show five thermal events. Three which correspond to the ones that were observed in the non modified clays (labeled 1 to 3 ) and one exothermic multi peak, labeled 4 and a fifth broad one (labeled 5). The exothermic peaks, labeled 4 , correspond to the decomposition of the quaternary ammonium salts. The same events were observed for all organoclays and the corresponding peak temperatures are reported in Table 4 and will be discussed below. Peak 5 can be attributed to decomposition of residual organic carbonaceous residue of the ammonium salts. The temperature at which this event occurs is the same for all the salts. It can be seen for the organoclays DTA curves, that peak 1 was shifted to lower temperatures (between

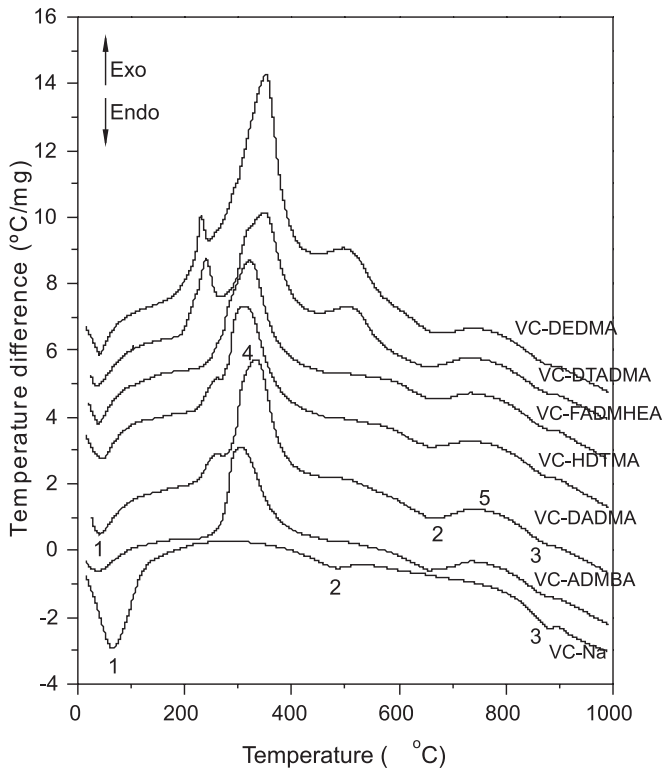

Figure 4. Differential thermal analysis (DTA) of sodium and organophilic clays

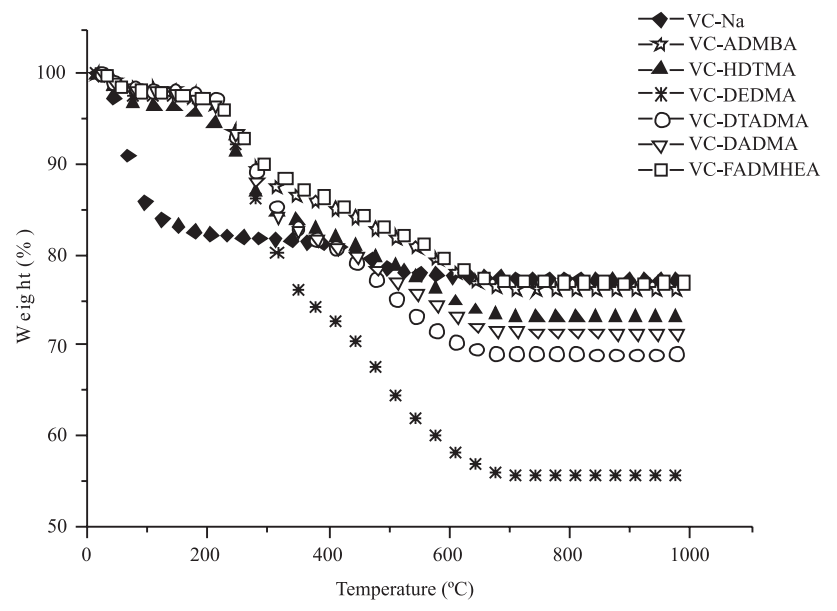

Figura 5. Mass loss curves of the sodium and organophilic clays studied here

about 25 and $150^{\circ} \mathrm{C}$ ) and peak 2 was shifted to higher temperatures (between about 550 and $700{ }^{\circ} \mathrm{C}$ ).

Table 5 presents the percentage of $\mathrm{H}_{2} \mathrm{O}$ evolved by dehydration of the clay (first endothermic peak) and the peak temperatures. Table 5 also shows the total mass loss of sodium and organophilic clays and the mass loss corresponding to the decomposition of the organic cations. The mass loss results were obtained from Figure 5, using the whole range of temperatures scanned in the TG analyses. The percentages of mass loss of the organic cations were estimated subtracting the mass loss of sodium clay, from 200 to $800{ }^{\circ} \mathrm{C}$, due to dehydroxylation, from the total mass loss of the organoclays, from 200 to $850{ }^{\circ} \mathrm{C}$, following the procedures of Hedley et al.. ${ }^{24}$

The water loss at low temperatures, between 25 and $200^{\circ} \mathrm{C}$ (peak 1 in Figure 4) is associated to water weakly physicadsorbed or with free water adsorbed either on the surface or on the layer edges of the clay particles. It can be seen that when the clay is modified, the dehydration temperature shifts to lower values, and the amount of water eliminated decreases. This behavior is due to the increase of the hydrophobic character of the modified clay. A similar behavior has been observed by Xie et al. ${ }^{15}$ 
Table 4. Differential thermal analysis results of sodium and organophilic clays

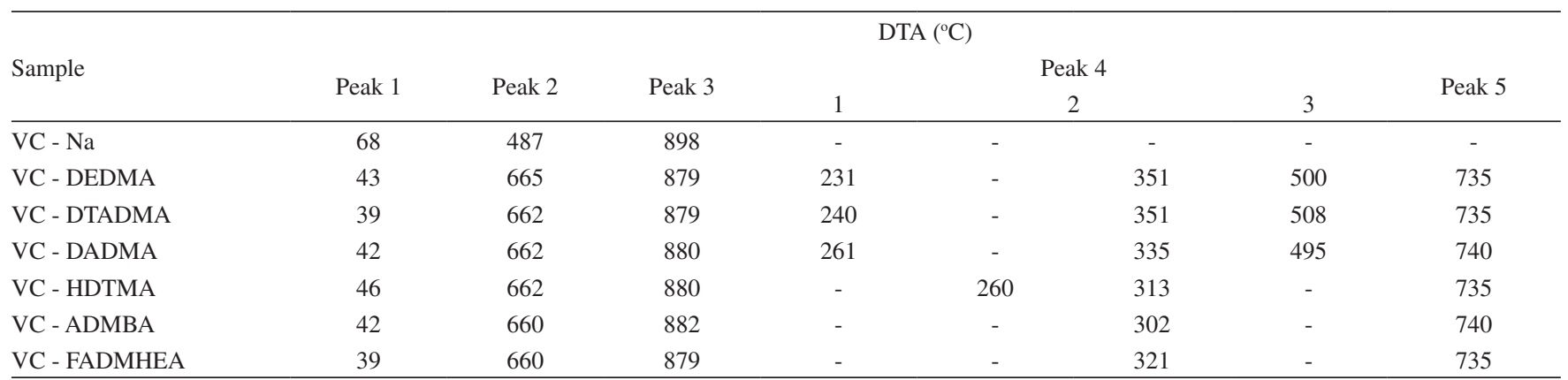

Table 5. Temperatures and relative mass loss corresponding to the dehydration, and surfactant decomposition

\begin{tabular}{|c|c|c|c|c|c|c|}
\hline \multirow[b]{2}{*}{ Sample } & \multicolumn{2}{|c|}{ Peak 1} & \multicolumn{3}{|c|}{ Peak 4} & \multirow[b]{2}{*}{$\begin{array}{l}\text { total mass loss } \\
(\%)\end{array}$} \\
\hline & Temperature $\left({ }^{\circ} \mathrm{C}\right)$ & $\begin{array}{l}\text { water } \\
\text { (wt.\%) }\end{array}$ & $\begin{array}{l}\text { surfactant mass loss } \\
(\%)\end{array}$ & $\begin{array}{l}\text { Onset temperature } \\
\left({ }^{\circ} \mathrm{C}\right)\end{array}$ & $\begin{array}{c}\text { mass loss (until } 200{ }^{\circ} \mathrm{C} \text { ) } \\
(\%)\end{array}$ & \\
\hline $\mathrm{VC}-\mathrm{Na}$ & 68 & 17 & - & - & - & 20.2 \\
\hline VC - DEDMA & 43 & 2.5 & 38.3 & 171 & 0.7 & 44 \\
\hline VC - DTADMA & 39 & 1.8 & 26.0 & 167 & 1.5 & 31 \\
\hline VC - DADMA & 42 & 1.9 & 23.9 & 180 & 0.8 & 29 \\
\hline VC - HDTMA & 46 & 3.4 & 20.4 & 181 & 0.2 & 27 \\
\hline VC - ADMBA & 42 & 1.6 & 19.2 & 181 & 2.4 & 24 \\
\hline VC - FADMHEA & 39 & 1.9 & 17.9 & 160 & 5.6 & 23 \\
\hline
\end{tabular}

The thermal event labeled 2 corresponds to the release of structural hydroxyl of the clays. This thermal event can be affected by the release of the water that is still present within the interlayer space, at temperatures higher than $200{ }^{\circ} \mathrm{C}$. This water occupies the empty spaces between the alkyl ammonium ions and can only be released at higher temperatures, because it is strongly bound to sodium ions, which were not exchanged by organic cations. It can be seen from Figure 4 that the intensity and width of event 2 for organophilic clays are larger than for sodium clays. Since the mass loss originated from the release of structural hydroxyl should be the same for all the clays studied here, and the modified clays are hydrophobic, this increase of intensity and width indicates that the event labeled 2 is superposed with the beginning of event 5 .

Table 4 presents the exothermic peaks corresponding to the release of surfactant (peak4) and Table 5 presents the surfactant mass loss. It can be seen from Table 4 that the release of organic cations occurs in steps: the one-tailed organoclays present one or two DTA peak whereas the two-tailed organoclays always present three DTA peaks. The thermal analyses of commercial salts showed that their decomposition occur in steps. The mass losses due to the salt main decomposition occur at peak temperatures of about $250{ }^{\circ} \mathrm{C}$, and of about $270{ }^{\circ} \mathrm{C}$, for one-tailed and two-tailed salts, respectively (see Figure 6). It can be seen from Tables 4 and 5 that the larger the release of organic cations, the higher the number of peaks in the DTA curves. According to the literature, ${ }^{23}$ when organic cations substitute the metallic cations present in an hydrophilic clay, they adhere mainly to the interlayer tetrahedrical sheet surface via electrostatic interactions. If the surfactant concentration added to the organoclays is increased, some cations in excess will be either attached to the external surface of the clay particles, but the majority of the excess surfactant will reside within the clay platelets either attached to the tetrahedrical sheet surface or adsorved by van der Waals forces to the chains of other cations. These different locations of the salts will result in several exothermic events. Peak 4 in Table 4 can be and was divided in three different exothermic events, called 1, 2, and 3. By comparing the DTA curves of the pure salts with the ones of organoclays, it can be concluded that the first exothermic event (called 1, in
Table 4) present in DTA curves of VC-DEDMA, VC-DTADMA, VCDADMA (two-tailed salts) samples, between $230-260^{\circ} \mathrm{C}$, is associated to the decomposition of the surfactant weakly attached to the surface of the clay particles. The higher temperature exothermic event (called 2 , in Table 4) corresponds to the decomposition of interlayer organic cations (peaks at about $260^{\circ} \mathrm{C}$, and peaks between $300-350^{\circ} \mathrm{C}$ ) because the peak temperatures are higher than the one of pure salts due to the protecting effect of the clay layers. V-ADMBA and VC-FADMHEA with less salt in excess (see Table 4, peak 4) present only the interlayer surfactant decomposition peaks (temperatures between $300-320{ }^{\circ} \mathrm{C}$ ). When the organic cation concentration is larger (which is the case of the four other salts), a larger cation number can occupy the interlayer spacing, increasing the number of peaks, peak temperatures and peak intensity. An overlapping of interlayer surfactant decomposition peaks can be observed for VC-DADMA, VC - DTADMA, and VC - DEDMA: for VC-HDTMA samples, it was possible to distinguish two different interlayer surfactant decomposition peaks, at about 260 and at $313^{\circ} \mathrm{C}$ (subdivision 2 of peak 4, in Table 4); for VC - DTADMA, VCDADMA and VC - DEDMA, only the temperature of the maximum intensity peak was detected (around $350^{\circ} \mathrm{C}$ ). These results indicate that the concentration of salt that is incorporated within the platelets during the cation exchange depends not only on the concentration of salt used (which was kept constant for all the salts studied here) to treat the clay, but also on the salt architecture once within the clay platelets. It would be expected, that the release of volatiles from the decomposition of two long alkyl chain salts happens at lower temperatures since they present the largest layer opening (Table 3). This is not the case. The interlayer surfactant decomposition events for VC-DEDMA, VC-DTADMA, VC-DADMA also present degradation temperatures in the range from $490-510^{\circ} \mathrm{C}$ (subdivision 3 of peak 4, in Table 4), which are higher than the temperatures for the one chain salts. This can be explained by the larger fraction of long chain decomposition products within the galleries for the two-tailed organoclays, which results in a decreased interlayer mobility. ${ }^{15}$ Therefore, the volatile evolution of two-tailed organoclays occurs at higher temperatures than the one for one-tailed organoclays, despite the larger interlayer spacing. 


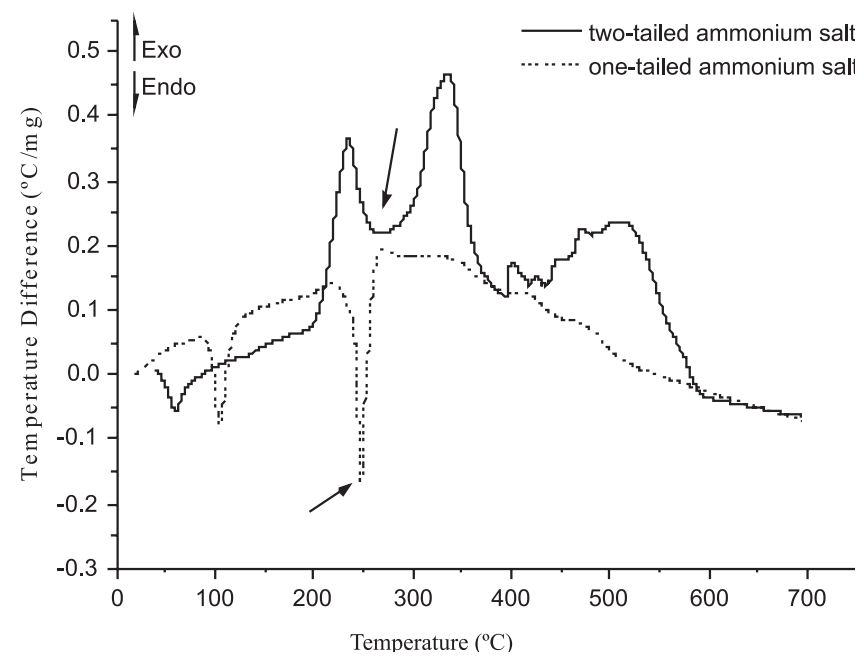

Figure 6. DTA curves of one-tailed and two-tailed ammonium salts

During nanocomposite preparation by melt blending, mainly those with polyolefin matrices, the processing temperatures range from 160 to $200{ }^{\circ} \mathrm{C}$. It can be seen from Figure 5 and 6 that the mass loss corresponding to the beginning of the decomposition of the organic cation starts at temperatures below $200{ }^{\circ} \mathrm{C}$. Table 5 presents the organic cation mass loss fraction up to $200{ }^{\circ} \mathrm{C}$, and the temperature at which $\partial^{2} \mathrm{w} / \partial \mathrm{T}^{2}$ shows a discontinuity, which corresponds to the onset temperature of the surfactant decomposition.

Figure 7 shows the onset surfactant decomposition temperature and basal spacing values as a function of surfactant fraction adsorbed by the clays (surfactant mass loss). It can be seen that the lower and larger surfactant concentration correspond to the lowest decomposition temperatures. The small interlayer surfactant concentration for VC-FADMHE results in a less dense interlayer which facilitate the release of the salt. At higher surfactant concentration, and at higher basal spacing values, excess salt is adsorved at the surface and edge of the clays. This excess cations are weakly attached and are released at lower temperatures, as it can be observed for the onset temperature of VC-DEDMA and VC-DTADMA samples.

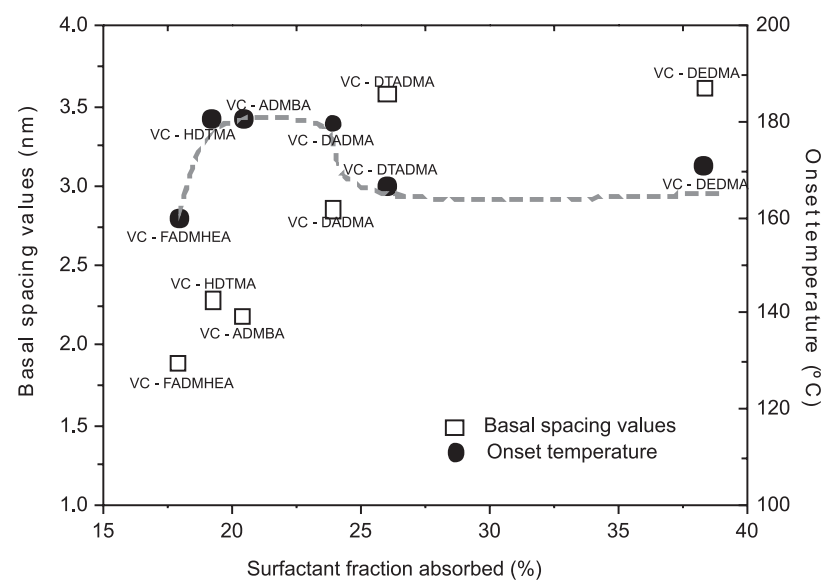

Figure 7. Surfactant decomposition temperature and basal spacing values as a function of surfactant fraction adsorbed by the clays

\section{CONCLUSIONS}

In this work, a Brazilian smectic clay was turned organophilic using quaternary ammonium salt of different structures. The conformation of the salts within the platelets of the clay depended on the number of long alkyl chains present in the structure of the salt. Two-tailed organoclays exhibit paraffin-type arrangements in the interlayer space of clays, whereas the one-tailed organoclays present bilayer and pseudotrimolecular arrangements. The thermal stability of the salts was also investigated. The results indicated that the surfactant decomposition occurs at temperatures lower than the ones normally used for the melt blending of the polymers. It was observed in this study that organoclays with a very high or a very low surfactant concentration present the lowest surfactant decomposition onset temperature, due to the surfactant location within the clay structure. The cation organic position depends on the architecture of the salt used to modify the clays, which, in turns, determines the organic cation concentration in the clay structure. Therefore, care should be taken in the choice of the salt to modify a clay, in order to avoid its decomposition during nanocomposite preparation. Such decomposition could cause the decrease in the interlayer spacing and alter the interface modified clay/polymer, making it more difficult to obtain nanocomposites with morphologies that lead to improved matrix properties.

\section{ACKNOWLEDGMENTS}

The authors would like to acknowledge FAPESP, CAPES and $\mathrm{CNPq}$ for financial support.

\section{REFERENCES}

1. Alexandre, M.; Dubois, P.; Mater. Sci. Eng. 2000, 28, 1.

2. Utracki, L. A.; Clay-Containing Polymeric Nanocomposite, $1^{\text {st }} \mathrm{ed}$., Rapra Technology Limited: Shawbury, 2004, vol. 1.

3. Bergaya, F.; Theng, B. K. G.; Lagaly, G., eds.; Handbook of Clays Science, $1^{\text {st }}$ ed., Elsevier Science: Amsterdan, 2006.

4. Carastan, D. J.; Demarquette, N. R.; Int. Mater. Rev. 2007, 52, 345.

5. Demarquette, N. R.; Carastan, D. J.; Valera, T. S. In Recent Advances in Polymer Nanocomposites; Thomas, S.; Zaikov, G., eds.; Nova Science Publishers: New York, 2008, p. 327-378.

6. Okada, A.; Usuki, A.; Macromol. Mater. Eng. 2006, 291, 1449.

7. Saito, T.; Okamoto, M.; Hiroi, R.; Yamamoto, M.; Shiroi, T.; Polymer 2007, 48, 4143.

8. Okamoto, M. In Macromolecular Engineering. Precise synthesis, materials properties, applications; Wiley-VCH Verlag $\mathrm{GmbH} \& \mathrm{Co}$. KGaA: Weinheim, 2007, vol. 4.

9. Vieira Coelho, A. C.; Souza Santos, P.; Souza Santos, H.; Quim. Nova 2007, 30, 1282.

10. Paiva, L. B.; Morales, A. R.; Valenzuela Díaz, F. R.; Appl. Clay Sci. 2008, 42,8 .

11. Grim, R. E.; Clay Mineralogy, McGraw-Hill: New York, 1968.

12. Souza-Santos, P.; Tecnología de argilas aplicada as argilas brasileiras, Fundamentos, 2a ed., Edgar Blucher: Sao Paulo, 1989, vol. 1.

13. Valera, T. S.; Lins, P. G.; Demarquette, N. R.; Santos, A. M.; XIV International Clay Conference, Castellaneta Marina, Italy, 2009.

14. Favre, H.; Lagaly, G.; Clay Miner. 1991, 26, 19.

15. Xie, W.; Gao, Z.; Pan, W. P.; Hunter, D.; Singh, A.; Vaia, R.; Chem. Mater. 2001, 13, 2979.

16. Xie, W.; Xie, R.; Pan, W. P.; Hunter, D.; Koene, B.; Tan, L.-S.; Vaia, R.; Chem. Mater. 2002, 14, 4837.

17. VanderHart, D. L.; Asano, A.; Gilman, J. W.; Chem. Mater. 2001, 13, 3796.

18. Hlavatý, V.; Fajnor, V. S.; J. Therm. Anal. Calorim. 2002, 67, 113.

19. Lee, S. Y.; Kim, S. J.; Clay Miner. 2003, 38, 225.

20. Yariv, S.; Appl. Clay Sci. 2004, 24, 225. 
21. Xi, Y.; Ding, Z.; He, H.; Frost, R. L.; J. Colloid Interface Sci. 2004, 277, 116.

22. Xi, Y.; Martens, W.; He, H.; Frost, R. L.; J. Therm. Anal. Calorim. 2005, 81, 91 .

23. Xi, Y.; Zhou, Q.; Frost, R. L.; He, H.; J. Colloid Interface Sci. 2007, $311,347$.

24. Hedley, C. B.; Yuan, G.; Theng, B. K. G.; Appl. Clay Sci. 2007, 35, 180.

25. Araújo, E. M.; Barbosa, R.; Morais, C. R. S.; Soledade, L. E. B.; Souza, A. G.; Vieira, M. Q.; J. Therm. Anal. Calorim. 2007, 90, 841.

26. Araújo, E. M.; Rodrigues, A. W. B.; Melo, T. J. A.; Ito, E. N.; Mater. Sci. Eng., A 2007, 445-446, 141.

27. Araújo, E. M.; Melo, T. J. A.; Oliveira, A. D.; Araújo, H. L. D.; Araújo, K. D.; Barbosa, R.; Polímeros 2006, 16, 38.

28. Nogueira, R. F.; Tavares, M. I. B.; San Gilc, R. A. S.; da Silva, N. M.; Polym. Test. 2005, 24, 358.

29. Leite, A. M. D.; Maia, L. F.; Araújo, E. M.; Lira, H. L.; J. Appl. Polym. Sci. 2009, 113, 1488.

30. Barbosa, R.; Araújo, E. M.; Melo, T. J. A.; Ito, E. N.; Mater. Lett. 2007, 61, 2575.

31. Barbosa, R.; Araújo, E. M.; Melo, T. J. A.; Ito, E. N.; Hage Jr., E.; J. Nanosci. Nanotechnol. 2008, 8, 1937.
32. Medeiros, V. N.; Araújo, E. M.; Maia, L. F.; Pereira, O. D.; Arimateia, R. R.; Paz, R. A.; Polímeros 2008, 18, 302.

33. Rodrigues, A. W.; Brasileiro, M. I.; Araújo, W. D.; Araújo, E. M.; Neves, G. A.; de Melo, T. J. A.; Polímeros 2007, 17, 219.

34. Ribeiro, S. P. S.; Estevão, L. R. M.; Pereira, C.; Rodrigues, J.; Nascimento, R. S. V.; Polym. Degrad. Stab. 2009, 94, 421.

35. Kitsopoulus, K. P.; Clays Clay Miner. 1999, 47, 688.

36. Botelho, K. T.; Monteiro, A. F.; Pereira, K. R.; Wiebeck, H.; Valenzuela Diaz, F. R.; Congresso Brasileiro de Cerâmica, Florianópolis, Brasil, 2008.

37. Valenzuela Díaz, F. R.; Abreu, L. D. V.; Santos, P. S.; Cerâmica 1996, 42, 290.

38. Silva, A. A.; Valenzuela-Diaz, F. R.; Martins, G. S. V.; Rodrigues, M. G. F.; Cerâmica 2007, 53, 417.

39. Vianna, M. M. G. R.; Franco, J. H. R.; Pinto, C. A.; Valenzuela Díaz, F. R.; Bucheler, P. M.; Braz. J. Chem. Eng. 2004, 2, 239.

40. Valenzuela Díaz, F. R.; Key Eng. Mater. 2001, 203, 189.

41. Foster, M. D.; Am. Mineral. 1953, 38, 994.

42. Moore, D. M.; Reynolds Jr., R. C.; X-Ray diffraction and the identification and analisis of clay minerals, Oxford University Press: New York, 1989.

43. Adebajo, M. O.; Frost, R. L.; Kloprogge, J. T.; Carmody, O. J.; Porous Mater. 2003, 10, 159. 